\title{
PRIZNANJA ZA POSEBNE DOSEŽKE PRI UČENJU ODRASLIH - LETOS ŽE ČETRTIČ
}

S če nočemo pristati na obrobju, če želimo biti dejavno vključeni v njegovo zgodbo, se moramo spreminjati $z$ njim. Da bi spremembe razumeli in z njimi tudi osebnostno rasli, da bi videli prek vzorcev, ki nam jih ponuja vsakdanjik, se moramo nenehno izpopolnjevati. Informacijska družba je namreč nevarno okolje, če se ne oborožimo z znanjem, in izzivi demokracije so le utvare, če politična svoboda ni podprta s poznavanjem okvirov, v katerih jo lahko uresničujemo.

Vseživljenjsko učenje je torej ključ za uspešno delovanje na mnogih ravneh. Da bi nam bilo tudi v veselje, je Andragoški center RS pred petimi leti zasnoval Teden vseživljenjskega učenja, ki je postal praznik učeče se družbe oziroma vseh učečih se ljudi v vseh življenjskih obdobjih in okoljih. Posebej slovesno razsežnost je dobila prireditev leta 1997, ko je bilo podeljenih prvih petnajst priznanj kreativnim posameznikom, organizacijam, lokalnim skupnostim ter različnim skupinam civilne družbe, ki so se posebej izkazali pri izpopolnjevanju lastnega znanja ali bogatitvi znanja drugih. Odtlej v Andragoški center iz leta $\mathrm{v}$ leto prispe več predlogov za priznanja in s tem se priznanjem povečuje tudi pomen. Predlagani so na videz anonimni posamezniki, ki so se znašli v slepi ulici in ugotovili, da jim bo le novo znanje vlilo pravšnjo samozavest (včasih se zdi niz izobraževalnih programov, ki jih je posameznik opravil, skoraj neskončno dolg); med zgledi, ki pritegnejo, najdemo župane, mentorje študijskih krožkov, vodje različnih delavnic in klubov, univerzo za tretje življenjsko obdobje, fakultete, šole, zavode, skupine za pomoč in samopomoč, krajevne skupnosti, podjetja ...

Njihove zgodbe si je mogoče prebrati na spletnih straneh TVU (www.acs.si/tvu.htm) sebi za spodbudo ali pa tudi kot zgled, koga predlagati za letošnjo podelitev priznanj. Pravzaprav vabimo bralce, naj se ozrejo okrog sebe, da bi opazili skupine ali posameznike, ki so z veliko poguma, prizadevnosti in marsikdaj tudi odpovedi pomembno obogatili lastno znanje, in naj nam te lepe zglede predstavijo. Prav tako naj se s predlogi za priznanja oglasijo vsi, ki poznajo posameznike, skupine, ustanove, podjetja ali lokalne skupnosti, ki dosegajo izjemne strokovne ali promocijske dosežke pri bogatitvi znanja drugih. Upoštevajte določila razpisa za priznanja (objavljamo ga na zadnji strani Novičk) in roke. Prijavni obrazci so na voljo v Andragoškem centru Slovenije, če boste poklicali po telefonu 01/85 842560 , pa vam jih bomo poslali.

S. B. K. 